Article

\title{
New Engineered-Botulinum Toxins Inhibit the Release of Pain-Related Mediators
}

\author{
Minhong Tang, Jianghui Meng * and Jiafu Wang * \\ School of Biotechnology, Faculty of Science and Health, Dublin City University, Collins Avenue, Glasnevin, \\ Dublin 9, Ireland; minhong.tang3@mail.dcu.ie \\ * Correspondence: jianghui.meng@dcu.ie (J.M.); jiafu.wang@dcu.ie (J.W.); Tel.: +353-1700-7351 (J.M.); \\ +353-1700-7489 (J.W.)
}

Received: 5 December 2019; Accepted: 27 December 2019; Published: 30 December 2019

\begin{abstract}
Targeted delivery of potent inhibitor of cytokine/pain-mediator into inflammatory or pain-sensing cells is a promising avenue for treating chronic pain, a world-wide major healthcare burden. An unmet need exists for a specific and effective delivery strategy. Herein, we describe a new approach using sortase to site-specifically ligate a non-toxic botulinum neurotoxin D (BoNT/D) core-therapeutic (synaptobrevin-cleaving protease and translocation domains) to cell-specific targeting ligands. An engineered core-therapeutic was efficiently ligated to IL-1 $\beta$ ligand within minutes. The resultant conjugate specifically entered into cultured murine primary macrophages, cleaved synaptobrevin 3 and inhibited LPS/IFN- $\gamma$ evoked IL- 6 release. Likewise, a CGRP receptor antagonist ligand delivered BoNT/D protease into sensory neurons and inhibited $\mathrm{K}^{+}$-evoked substance $\mathrm{P}$ release. As cytokines and neuropeptides are major regulators of inflammation and pain, blocking their release by novel engineered inhibitors highlights their therapeutic potential. Our report describes a new and widely-applicable strategy for the production of targeted bio-therapeutics for numerous chronic diseases.
\end{abstract}

Keywords: cytokine; neuropeptides; neurotoxin; therapeutics; targeting; protein conjugation

\section{Introduction}

Chronic pain, including rheumatoid arthritis (RA), is still a major medical challenge, with a high number of people suffering from persistent pain worldwide. Currently, three main types of medicine are widely used to treat chronic pain, including nonsteroidal anti-inflammatory drugs (NSAIDs) and opioids with adjuvants such as antidepressants and anticonvulsants. Unfortunately, these medications are largely ineffective or unsuitable for many sufferers of chronic pain, either due to their short half-lives or various unacceptable adverse side effects, including addiction and overdose [1]. Thus, a pressing unmet need exists for persistently-acting and non-addictive medication for chronic pain.

Toward this end, botulinum neurotoxins (BoNTs) have been proposed to hold significant potential as local treatments for chronic pain. Clinical research demonstrated that after treatment with BoNT/A complex $\left(\mathrm{BOTOX}^{\circledR}\right)$ to migraine patients, their headache pain symptoms were significantly alleviated, and the frequency and duration of migraines were also reduced [2]. There are seven serotypes of BoNTs present in nature, termed BoNT/A to BoNT/G, each with a molecular weight of approximately $150 \mathrm{kDa}$. Sequence comparison combined with employing serotype-specific antibodies has revealed dozens of BoNT subtypes (BoNT/A1, BoNT/A2, BoNT/B2, etc.) and mosaic toxins (e.g., BoNT/CD, BoNT/DC, BoNT/FA(H)) [3-8]. Moreover, using bioinfomatics analysis approach, a novel serotype BoNT/X was discovered [9]. BoNT serotypes are similar in both general function and structure, consisting of a $\approx 50 \mathrm{kDa}$ N-terminal protease light chain domain $(\mathrm{LC})$ and a $\approx 100 \mathrm{kDa}$ C-terminal heavy chain domain (HC), linked via a disulphide bond. Most of BoNTs target neurons by binding to gangliosides and 
the synaptic vesicle protein 2 (serotypes: /A, /D-/F) or synaptotagmin (/B and /G) via the C-terminal half of $\mathrm{HC}\left(\mathrm{H}_{\mathrm{C}}\right)$ (in [10]). Once BoNTs get internalised into the neurons, the $\mathrm{N}$-terminal half of $\mathrm{HC}$ $\left(\mathrm{H}_{\mathrm{N}}\right)$ forms a channel on the synaptic vesicle and/or endosomal membrane, allowing for translocation of the attached LC to the cytosol [11]. This active LC protease can then cleave and inactivate soluble $\mathrm{N}$-ethylmaleimide-sensitive factor attachment protein receptors (SNAREs). Synaptosomal-associated protein $25 \mathrm{kDa}$ (SNAP-25) is cleaved by LC/A,/C1 and/E whereas synaptobrevin, also known as vesicle associated membrane protein (VAMP) isoform 1, 2 and 3 are truncated by LC/B,/D,/F and/G. BoNT/C1 additionally cleaves syntaxin 1 . Uniquely, BoNT/X not only truncates VAMP 1, 2 and 3, but also non-traditional SNAREs, such as VAMP4, VAMP5 and Ykt6 [9], possibly extending the therapeutic uses of BoNTs. Cleavage of these SNAREs results in the disruption of the vesicle fusion and blockade of transmitter release (reviewed in [10]). BoNT serotypes/A and /B complex forms have been widely used for treating hyper-excitability disorders of cholinergically innervated muscles or glands. In 2010, BOTOX ${ }^{\circledR}$ was approved by the FDA to treat chronic migraines [12]. As an analgesic agent, it has the advantage of being non-additive and of having a long duration of action, due to persistent cleavage of SNAP-25 [12,13]. However, BoNTs can produce unwanted secondary effects (e.g., muscle paralysis), often due to diffusion of the toxin from the injection site to non-targeted structures [14]. To avoid the unwanted muscle paralysis side effect associated with the treatment of chronic pain, improvement of BoNT is desired so that it will selectively and specifically target BoNT SNARE-cleaving protease into inflammatory cells and/or sensory neurons rather than motor neurons.

RA is a common autoimmune disorder characterized by chronic joint inflammation, swelling and pain. Macrophages are known to play an important role in the pathogenesis and progression of RA, primarily through the secretion of various inflammatory mediators, resulting in cartilage and bone destruction [15]. The most important pro-inflammatory cytokines which play an essential role in the development of RA are tumor necrosis factor- $\alpha(\mathrm{TNF} \alpha)$, interleukin $1 \beta$ (IL-1 $\beta)$ and IL-6 [16-18]. TNF $\alpha$ and IL-6 sensitize joint nociceptors to mechanical stimulation, and thus, directly contribute to mechanical hyperalgesia [19]. It is known that macrophages require VAMP3 to secrete cytokines [20,21]. Thus, targeted delivery of VAMP-cleaving protease into macrophages could offer a novel means for potential treatment of RA disease. Hence a site-specific, robust, reliable and efficient strategy for modification of BoNTs is highly desirable for generating retargeted BoNTs' proteases. In order to meet this demand, we exploited the sortase-mediated protein ligation technique to make functional targeted BoNT based fusion proteins by stitching BoNT protease to the cell-specific targeting ligands. Staphylococcus aureus sortase A, a thiol transpeptidase, exists in many Gram-positive bacteria and is responsible for covalent anchoring of cell surface proteins to bacterial cell walls [22]. Under physiological reaction conditions, proteins with an exposed LPXTG motif (X: any residue) can be specifically ligated by sortase A to an aminoglycine protein/peptide via an amide bond.

Using general molecular biology techniques, a short, non-structural linker followed by LPETG motif was attached to the C-terminal of long-acting BoNT/D core-therapeutic consisting of LC and $\mathrm{H}_{\mathrm{N}}$ domains lacking the neuronal binding domain $\mathrm{H}_{\mathrm{C}}\left(/ \mathrm{D} \Delta \mathrm{H}_{\mathrm{C}}\right)$. The resultant protein $/ \mathrm{D} \Delta \mathrm{H}_{\mathrm{C}}-\mathrm{CS}(\mathrm{CS}$ refers to the C-terminal sortase motif) was expressed in Escherichia coli and purified with retention of its full VAMP cleaving protease activity. This protein was ligated to a recombinantly produced interleukin $1 \beta$ (IL-1 $\beta$ ) or a synthesized calcitonin gene-related peptide (CGRP) receptor antagonist (CGRP $\left.{ }_{8-37}\right)$ within minutes via a sortase-catalyzed reaction to produce the retargeted BoNT/D based therapeutic candidates: /DIL-1 $\beta$ and /D-CGRP 8 -37, respectively. As macrophages express the IL-1 receptor $[23,24]$ and a fraction of small to medium-sized dorsal root ganglion neurons (DRGs) express the CGRP receptor [25], the above mentioned ligated ligands successfully delivered the BoNT/D core-therapeutic into either cultured macrophages or DRGs. This results in inhibiting the release of inflammatory cytokines or pain transmitter peptides (substance P). Thus, our findings indicate that these retargeted BoNT/D-based therapeutics possess anti-inflammatory and/or anti-nociceptive capabilities. Moreover, due to the rapid, reliable and robust nature of the method described herein, we believe that this 
retargeting strategy will prove to be a valuable and widely-applicable tool for the development of future BoNT-based therapeutics.

\section{Results}

\subsection{BoNT/D Core-Therapeutic with Sortase A Recognition Motif Was Expressed and Purified with Good Yield} and Purity

The sortase A-mediated conjugation strategy was chosen to re-direct BoNT/D core-therapeutic into the target cells. This method allows for efficient ligation of a targeting ligand (peptides or proteins with or without modification) to the core-therapeutic (Figure 1A). First, a synthetic gene fragment encoding LC. $\mathrm{H}_{\mathrm{N}}$ of BoNT/D (denoted /D $\Delta \mathrm{H}_{\mathrm{C}}$ ), with a codon optimized for E. coli expression, was inserted into the pET29a vector. Note that this synthetic gene contains a thrombin recognition consensus site at the loop region between the LC and $\mathrm{H}_{\mathrm{N}}$ domains, allowing for precise nicking. Subsequently, a short nucleotide sequence encoding a non-structural linker and a sortase A recognition motif (LPETG) followed by a thrombin recognition sequence was inserted between the $3^{\prime}$ end of $\mathrm{H}_{\mathrm{N}} / \mathrm{D}$ gene and vector nucleotides encoding a C-terminal $\mathrm{His}_{6}$ tag. This generated a construct, encoding $/ \mathrm{D} \Delta \mathrm{H}_{\mathrm{C}}-\mathrm{CS}$ (CS refers to the C-terminal sortase motif) (Figure 1B). After transformation of the resultant plasmid into $E$. coli BL21 DE3, /D $\Delta \mathrm{H}_{\mathrm{C}}-\mathrm{CS}$ was expressed in E. coli using an auto-induction medium and successfully purified by immobilised metal ion affinity chromatography (IMAC) with a yield of ( $\approx 4 \mathrm{mg} / \mathrm{L}$ of culture). $/ \mathrm{D} \Delta \mathrm{H}_{\mathrm{C}}-\mathrm{CS}$ was expressed and purified as the single-chain (SC) form with the predicted molecular weight ( $\approx 100 \mathrm{kDa}$ ) (Figure 1C). The purified/D $\Delta \mathrm{H}_{\mathrm{C}}-\mathrm{CS} S \mathrm{SC}$ was then nicked into the di-chain (DC) form by thrombin. This was examined by SDS-PAGE in the presence or absence of a reducing agent, dithiothreitol (DTT). The nicked sample remained a single band in the absence of the reducing agent, and its constituents ( $\mathrm{LC}$ and $\mathrm{H}_{\mathrm{N}}-\mathrm{CS}$ ) were only separated in the presence of DTT, confirming that the disulphide interchain was successfully formed in the E.coli (Figure 1D).

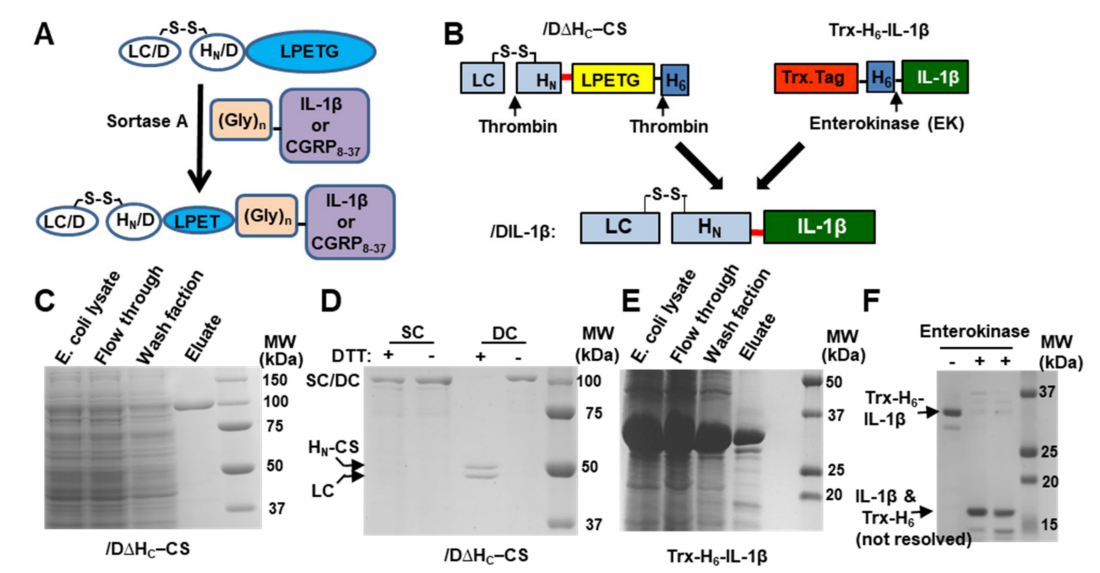

Figure 1. Protein engineering BoNT/D core-therapeutic and targeting ligand. (A) Schematic of the sortase A-mediated conjugation strategy. Sortase A can ligate recombinant (Gly) $)_{5}$-IL-1 $\beta$ or attach $(\mathrm{Gly})_{3}-\mathrm{CGRP}_{8-37}$ to the C-terminal of $\mathrm{LC} . \mathrm{H}_{\mathrm{N}} / \mathrm{D}$ via recognition of the LPETG motif and cleavage of the bond between T and G. (B) Illustration of protein engineering /DIL-1 $\beta$ via ligation of Gly $y_{5}-I_{L}-1 \beta$ to $/ \mathrm{D} \Delta \mathrm{H}_{\mathrm{C}}-\mathrm{CS}$ by sortase $\mathrm{A}$. $/ \mathrm{D} \Delta \mathrm{H}_{\mathrm{C}}-\mathrm{CS}$ depicts BoNT/D core-therapeutic with a C-terminal sortase and thrombin recognition motifs (see Methods). Trx: thioredoxin; $\mathrm{H}_{6}$ : His 6 tag; CS, C-terminal sortase motif. The red bold bar between $\mathrm{H}_{\mathrm{N}}$ and IL-1 $\beta$ denotes a short peptide sequence consisting of LPETG and non-structural linkers located on each end (see Methods). (C) $/ \mathrm{D} \Delta \mathrm{H}_{\mathrm{C}}-\mathrm{CS}$ was expressed in Escherichia coli and purified by IMAC. Aliquots from IMAC were analyzed by SDS-PAGE followed by Coomassie staining. (D) $/ \mathrm{D} \Delta \mathrm{H}_{\mathrm{C}}-\mathrm{CS} S \mathrm{~S}$ and thrombin-nicked di-chain (DC) were subjected to SDS-PAGE followed by Coomassie staining. (E) Purification of Trx- $\mathrm{H}_{6}-\mathrm{IL}-1 \beta$ fusion protein by IMAC. (F) SDS-PAGE analysis of Trx- $\mathrm{H}_{6}-\mathrm{IL}-1 \beta$ protein with or without enterokinase treatment. IL- $1 \beta$ and Trx- $\mathrm{H}_{6}$ have similar molecular weights $(\approx 17 \mathrm{kDa})$. 
2.2. Protein Engineering Inflammatory Cell Targeting Ligand and Its Efficient Conjugation to BoNT/D Core Therapeutic via Sortase Enzyme

To target BoNT/D core-therapeutic into inflammatory cells, we selected the IL-1 $\beta$ as a targeting ligand because IL-1 receptors are expressed on certain inflammatory cells, including macrophages, synoviocytes, etc. [23,24]. We inserted the synthetic gene encoding Gly 5 -IL-1 $\beta$ protein into a bacterial expression vector $\mathrm{pET} 32 \mathrm{~b}$ immediately after the enterokinase cleavage site to create a construct, encoding thioredoxin- $\mathrm{His}_{6}$-Gly -IL-1 $\beta$ protein (Figure $1 \mathrm{~B}$, abbreviated as Trx- $\mathrm{H}_{6}-\mathrm{IL}-1 \beta$ ). This strategy allows for enterokinase-mediated removal of the thioredoxin-His 6 tags from the Gly $y_{5}$ IL-1 $\beta$, and subsequent ligation of Gly $y_{5}-\mathrm{IL}-1 \beta$ to the BoNT/D core-therapeutic (Figure 1B). Similarly, Trx- $\mathrm{H}_{6}-\mathrm{IL}-1 \beta$ fusion protein was expressed in BL21.DE3 and purified by IMAC with a yield of $(\approx 60 \mathrm{mg} / \mathrm{L}$ of culture). Purified fusion protein was visualized on the Coomassie stained SDS-PAGE gel with $\mathrm{Mr} \approx 34 \mathrm{kDa}$ (Figure 1E). Incubation of fusion protein with enterokinase released Gly 5 -IL-1 $\beta$ from Trx-His 6 tags, yielding the predicted size of $\mathrm{Mr} \approx 17 \mathrm{kDa}$, corresponding to the removal of Trx-His ${ }_{6}$ tag (abbreviated as Trx- $\mathrm{H}_{6}$ ) (Figure 1F). As IL- $1 \beta$ and Trx- $\mathrm{H}_{6}$ are of similar molecular weight, they were not resolved by SDS-PAGE (Figure 1F).

Incubation of enterokinase cleaved product mixture with $/ \mathrm{D} \Delta \mathrm{H}_{\mathrm{C}}-\mathrm{CS}$ in the optimized reaction condition; sortase A rapidly ligated IL- $1 \beta$ to $/ \mathrm{D} \Delta \mathrm{H}_{\mathrm{C}}-\mathrm{CS}$ within $10 \mathrm{~min}$ to yield /DIL-1 $\beta$ conjugated protein. Further incubation did not result in higher yield (Figure 2A). /DIL-1 $\beta$ product was further purified by anion-exchange chromatography (AEX) to remove unbound IL- $1 \beta$ substrate and contaminant present (Figure 2B). The final product was analyzed by SDS-PAGE in the absence or presence of DTT. The majority of $/ \mathrm{D} \Delta \mathrm{H}_{\mathrm{C}}-\mathrm{CS}$ was conjugated to IL- $1 \beta$ (Figure $2 \mathrm{C}$, top band in the left lane) with mobility slower than the unconjugated form (Figure 2C, lower band in the left lane). In the presence of DTT, the LC/D and $\mathrm{H}_{\mathrm{N}} / \mathrm{D}-\mathrm{IL}-1 \beta$ were separated (Figure $2 \mathrm{C}$ ), confirming that the inter-chain disulphide bond was not affected by the reaction. The LC/D and sortase A-cleaved $\mathrm{H}_{\mathrm{N}}$-LPET in the un-conjugated protein were also segmented in the presence of DTT but not resolved in the SDS-PAGE due to having similar molecular weights (Figure 2C).
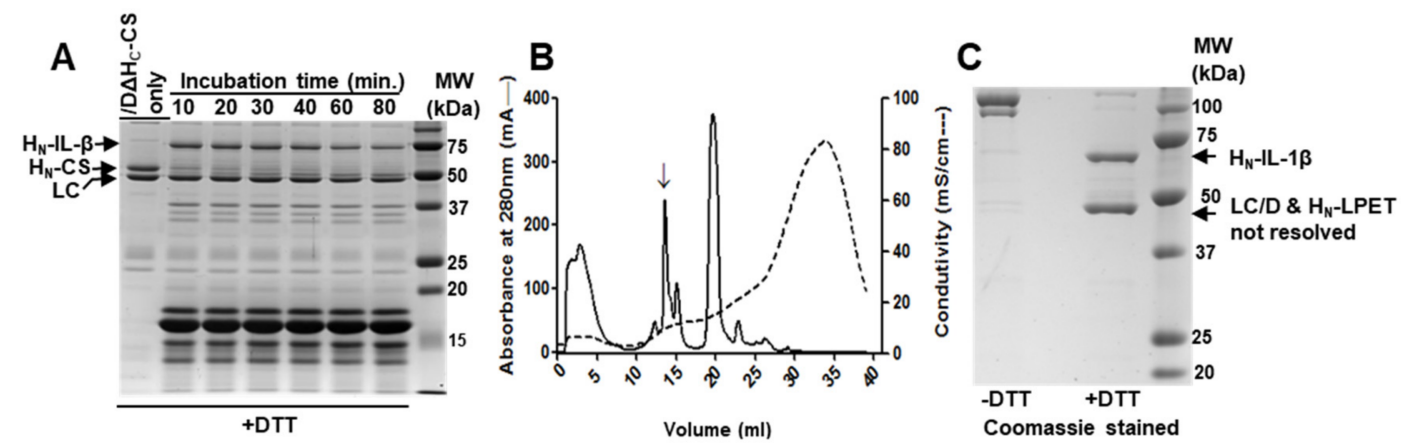

Figure 2. Production of /DIL-1 $\beta$. (A) $\mathrm{D} \Delta \mathrm{H}_{\mathrm{C}}-\mathrm{CS}$ was incubated with sortase $\mathrm{A}$, and enterokinase cleaved Trx- $\mathrm{H}_{6}$-IL-1 $\beta$ mixture at $37^{\circ} \mathrm{C}$. Samples were taken at different time points and subjected to SDS-PAGE in the presence of $50 \mathrm{mM}$ DTT followed by Coomassie staining. (B) Anion-exchange chromatography was used to separate /DIL-1 $\beta$ conjugate from the unconjugated product and contaminants. Arrow indicates the eluted peak for $/$ DIL- $1 \beta$. Solid line and broken line represent the absorbance and conductivity, respectively. (C) Pooled /DIL-1 $\beta$ product from B was subjected to SDS-PAGE followed by Coomassie staining.

\section{3. /DIL-1B Conjugate Exerts Receptor Binding and SNARE-Cleaving Biological Activities}

Next, it was important to confirm that, following ligation to $/ \mathrm{D} \Delta \mathrm{H}_{\mathrm{C}}-\mathrm{CS}$, the IL- $1 \beta$ component remained biologically active and could bind its cognate receptor. We used a cell proliferation method to assess its activity in RAW 264.7 macrophage cells. /DIL-1 $\beta$ application was found to promote cellular proliferation, showing only a slight, but not significant decrease of activity compared with commercial human IL-1 $\beta$ (Figure 3A). This confirms that the ligated product retains the bio-activity of its ligand. 
As expected, $/ \mathrm{D} \Delta \mathrm{H}_{\mathrm{C}}-\mathrm{CS}$ (the non-targeted control protein) did not induce cell proliferation (Figure $3 \mathrm{~A}$ ). Proteolytic activity was then investigated using a recombinant model substrate GFP-VAMP2 $2_{(2-94)}-\mathrm{His}_{6}$. The /DIL-1 $\beta$ conjugate was found to possess similar protease activity to the non-targeted control protein $\left(/ \mathrm{D} \Delta \mathrm{H}_{\mathrm{C}}-\mathrm{CS}\right)$ (Figure $\left.3 \mathrm{~B}\right)$. Thus, ligation of the targeting ligand to $/ \mathrm{D} \Delta \mathrm{H}_{\mathrm{C}}-\mathrm{CS}$ did not result in loss of ligand- or protease-mediated activity.
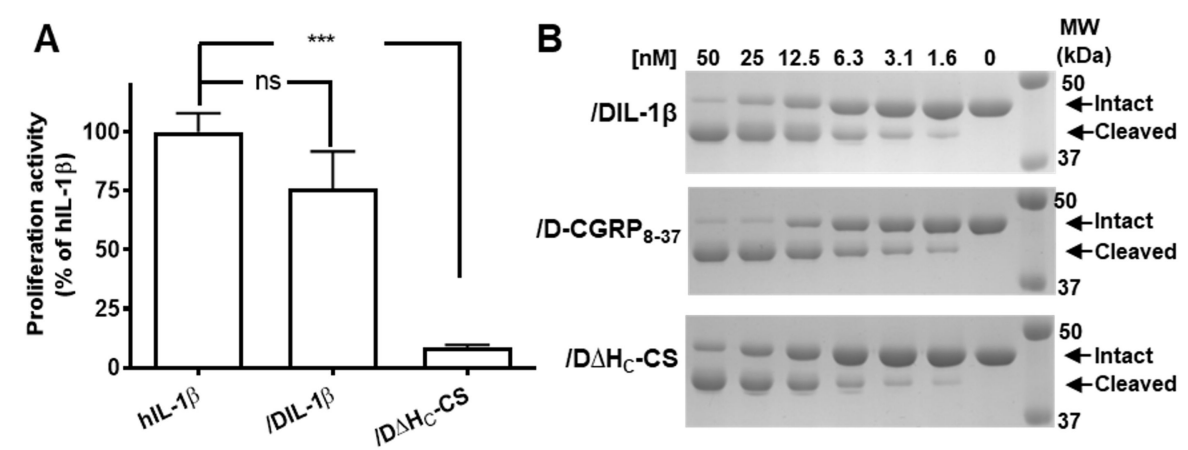

Figure 3. /DIL-1 $\beta$ retains biological activities of its ligand and protease. (A) Bar chart showing RAW cell proliferation activity of $/ \mathrm{DIL}-1 \beta$ and $/ \mathrm{D} \Delta \mathrm{H}_{\mathrm{C}}-\mathrm{CS}$ relative to commercial human IL- $1 \beta$. Data plotted are mean \pm S.E.M. $(n=3)$. ns: non-significant, ${ }^{* * *} p<0.001$. (B) $/ \mathrm{DIL}-1 \beta, / \mathrm{D}-\mathrm{CGRP}_{8-37}$ and $/ \mathrm{D} \Delta \mathrm{H}_{\mathrm{C}}-\mathrm{CS}$ have similar protease activities regarding cleaving a recombinant GFP-VAMP2 $2-94-\mathrm{His}_{6}$ substrate.

\subsection{IL-1ß Successfully Delivered BoNT/D VAMP-Cleaving Protease into RAW264.7 Cells and Primary Peritoneal Macrophages Resulting in Inhibition of IL-6 Release}

As mentioned in the introduction, macrophages play an important role in the pathogenesis of chronic inflammatory diseases, including RA. Macrophages also express the IL-1 receptor and certain SNARE proteins, especially SNAP-23 and VAMP3 $[23,24,26]$. Cultured RAW264.7 macrophages were treated with or without /DIL-1 $\beta$ for $6 \mathrm{~h}$ before stimulation of cytokine release with interferon gamma (IFN $\gamma$ ) and lipopolysaccharides (LPS) for $42 \mathrm{~h}$. Upon stimulation with IFN $\gamma$ and LPS, cultured macrophages secreted a large quantity of the pro-inflammatory cytokine IL-6 (Figure 4A). Importantly, /DIL-1 $\beta$ pretreatment resulted in both VAMP3 cleavage (Figure 4B and Figure S2) and a striking inhibition of IL-6 release (Figure $4 \mathrm{C}$ ). In contrast, the non-targeted control protein $/ \mathrm{D} \Delta \mathrm{H}_{\mathrm{C}}-\mathrm{CS}$ failed to achieve comparable VAMP3 cleavage (Figure 4B and Figure S2), and even at the highest concentration tested, only caused a slight inhibition of IL-6 release (Figure 4C). This experiment was then repeated on primary macrophages isolated from mouse peritoneal cavity. Similar to RAW264.7 macrophages, stimulation with IFN $\gamma$ and LPS promoted IL-6 release from cultured primary macrophages (Figure 4D). Reassuringly, /DIL-1 $\beta$ entered primary macrophages, truncated VAMP3 (Figure 4E and Figure S2) and attenuated IL-6 release more potently than the control protein (Figure 4F). Note that neither the targeted nor non-targeted control toxins affected cell viability (Figure S3). Thus, our results confirm that fused IL-1 $\beta$ can deliver BoNT/D protease specifically into macrophages. 

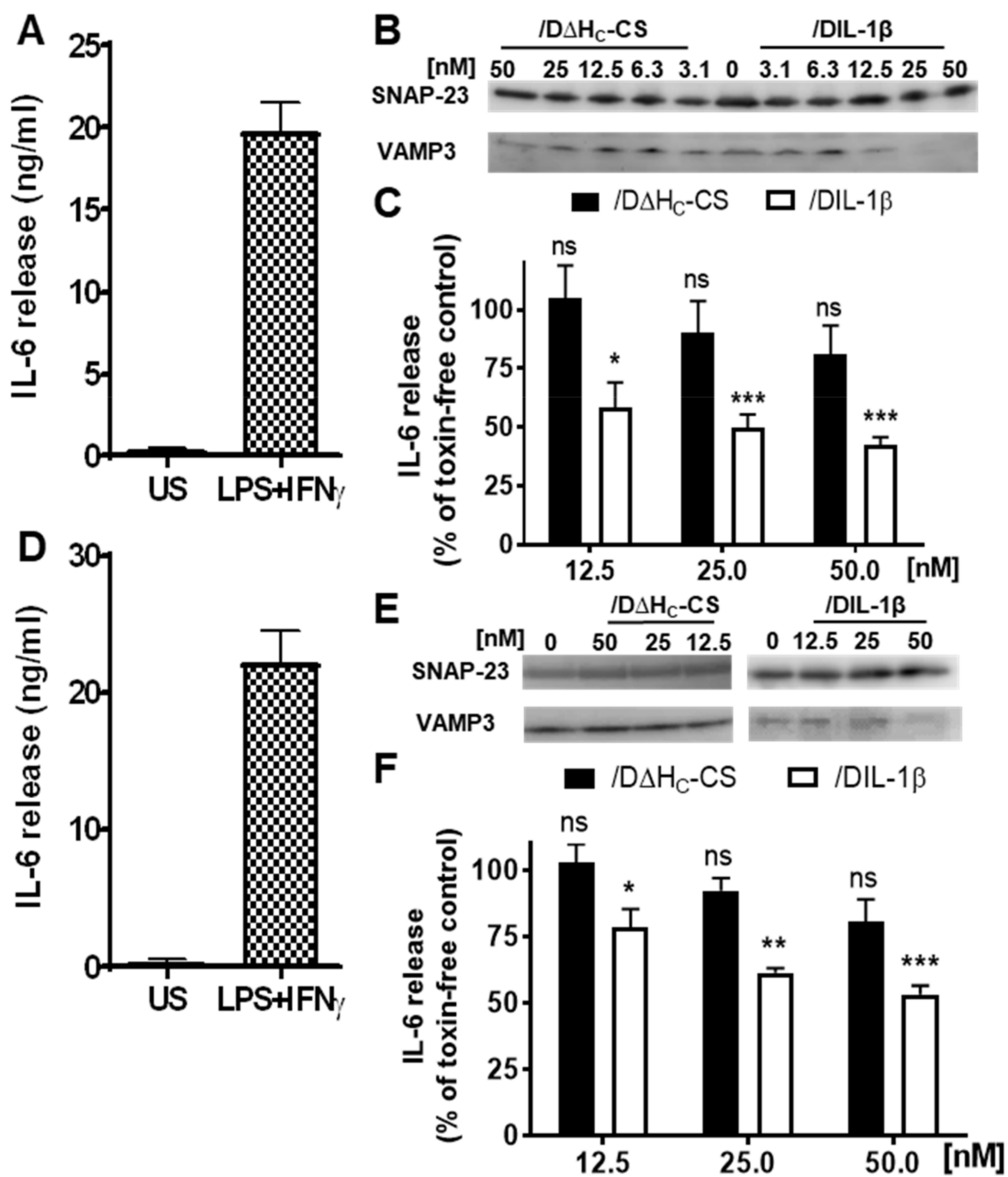

Figure 4. /DIL-1 $\beta$ entered the cultured macrophages, cleaved VAMP3 and inhibited evoked IL-6 release, unlike the untargeted control. (A) Treatment of RAW 264.7 cells with LPS and IFN $\gamma$ for $42 \mathrm{~h}$ induced substantial IL-6 release in comparison to unstimulated (US) cells. (B) Cleavage of VAMP 3 in RAW 264.7 cells by treated proteins was probed by Western blotting using an antibody against VAMP1/2/3 forms. Note that RAW cells predominately express the VAMP3 isoform (Figure S1). It is worth noting that the antibody used only recognises the intact but not the BoNT/D-protease-cleaved form. SNAP-23 was probed as an internal loading control. (C) /DIL-1 $\beta$ and $/ \mathrm{D} \Delta \mathrm{H}_{\mathrm{C}}-\mathrm{CS}$ inhibited LPS and IFN $\gamma$ evoked IL-6 release from the cultured RAW 264.7 cells to different extents. (D-F) Experiments were repeated as for $(\mathbf{A}-\mathbf{C})$, except primary mouse macrophage cells were used. Data plotted are mean \pm S.E.M. $(n=3)$. Significance between $/ \mathrm{DIL}-1 \beta$ or $/ \mathrm{D} \Delta \mathrm{H}_{\mathrm{C}}-\mathrm{CS}$ treated cells and toxin non-treated control cells is indicated as follows: non-significant (ns), $p>0.05 ;{ }^{*} p<0.05 ;{ }^{* *} p<0.01$ and ${ }^{* *} p<0.001$.

\subsection{Conjugating a CGRP Antagonist to /D $\Delta H_{C}-C S$ Targets Sensory Neurons and Inhibits Pain-Peptide Release}

Our results have confirmed that sortase A enzyme can efficiently ligate the small recombinant protein to the BoNT/D core therapeutic with retention of the biological activities of ligand and SNARE-cleaving protease. To target $/ \mathrm{D} \Delta \mathrm{H}_{\mathrm{C}}-\mathrm{CS}$ into sensory neurons for potential pain relief, we exploited a CGRP antagonist as a targeting ligand because a subset of sensory neurons are

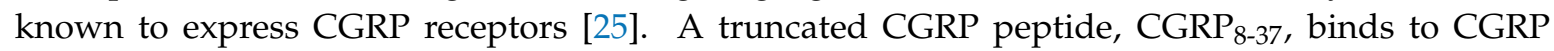
receptor and antagonizes CGRP activity [27]. After $30 \mathrm{~min}$ incubation of a synthesized Gly ${ }_{3}-\mathrm{CGRP}_{8-37}$ peptide with $/ \mathrm{D} \Delta \mathrm{H}_{\mathrm{C}}-\mathrm{CS}$ and sortase $\mathrm{A}, / \mathrm{D} \Delta \mathrm{H}_{\mathrm{C}}-\mathrm{CS}$ was ligated to $\mathrm{CGRP}_{8-37}$, yielding /D-CGRP $\mathrm{D}_{8-37}$ conjugate as demonstrated by a shift towards higher molecular size in the SDS-PAGE gel (Figure 5A,B). Anti-CGRP antibody recognized the /D-CGRP 8 -37 sample but not the $/ \mathrm{D} \Delta \mathrm{H}_{\mathrm{C}}$-CS (Figure $5 \mathrm{C}$ ), further confirming $\mathrm{CGRP}_{8-37}$ successfully conjugated to $/ \mathrm{D} \Delta \mathrm{H}_{\mathrm{C}}-\mathrm{CS}$. Cultured rat DRGs were incubated with 
or without /D-CGRP $8-37$ for $24 \mathrm{~h}$ before stimulation with $60 \mathrm{mM} \mathrm{KCl}$ for $30 \mathrm{~min}$. Depolarization of DRGs stimulated the release of substance P approximately 5-fold over basal release (Figure 5D). Treatment with /D-CGRP 8 -37 led to a significant cleavage of VAMP1, especially at $200 \mathrm{nM}$ (Figure 5E,F), resulting in a substantial reduction of potassium evoked substance P release (Figure 5G). In contrast, non-targeted control protein failed to cleave VAMP1 and inhibit substance P release (Figure 5E-G).

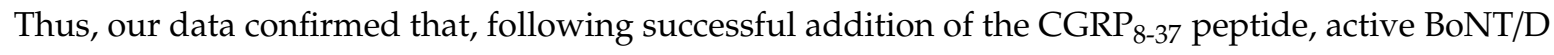
protease can be effectively targeted into sensory neurons.

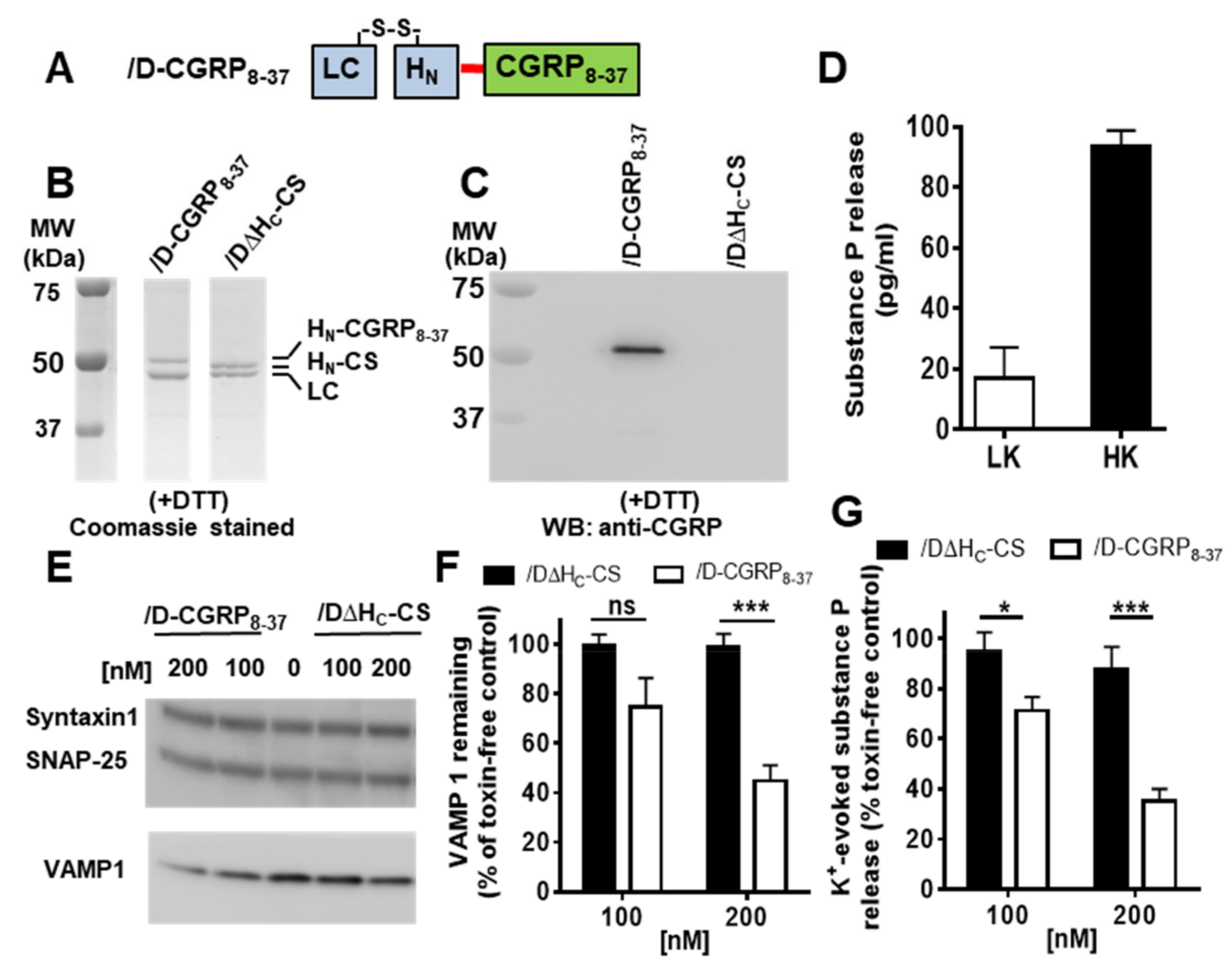

Figure 5. Conjugation of $\mathrm{CGRP}_{8-37}$ to $/ \mathrm{D} \Delta \mathrm{H}_{\mathrm{C}}-\mathrm{CS}$ yielded $/ \mathrm{D}-\mathrm{CGRP} \mathrm{P}_{8-37}$ which cleaved VAMP1 and inhibited depolarization evoked substance P release from cultured DRGs. (A) Schematic of /D-CGRP 8-37. (B, C) DTT reduced /D-CGRP ${ }_{8-37}$ and $/ \mathrm{D} \Delta \mathrm{H}_{\mathrm{C}}-\mathrm{CS}$ samples were analyzed by SDS-PAGE followed by Coomassie staining (B) or by Western blotting with a rabbit anti-CGRP antibody $(1: 10,000)(\mathbf{C})$. Uncropped original images are shown in Figure S4. (D) Depolarization of cultured DRGs stimulated the release of substance P approximately 5-fold over basal release (LK, low potassium; HK, high potassium). (E) Representative Western blots showing the cleavage of VAMP1 by /D-CGRP 8 -37 compared to $/ \mathrm{D} \Delta \mathrm{H}_{\mathrm{C}}-\mathrm{CS}$. Syntaxin1 and SNAP-25 were probed as loading control. (F) Intact VAMP1 remaining after incubating with $100 \mathrm{nM}$ or $200 \mathrm{nM}$ of either protein was calculated by expressing the ratio (intensity of VAMP1/the corresponding internal loading control (Syntaxin1)) as a percentage of the toxin free control sample. (G) /D-CGRP ${ }_{8-37}$ but not/D $\Delta \mathrm{H}_{\mathrm{C}}-\mathrm{CS}$ attenuated the $\mathrm{K}^{+}$-evoked substance $\mathrm{P}$ release when compared to the toxin-free sample. Data plotted in $(\mathbf{D}, \mathbf{F}, \mathbf{G})$ are mean \pm S.E.M. $(n=3)$. ns: non-significant, ${ }^{*} p<0.05$ and ${ }^{* * *} p<0.001$.

\section{Discussion}

Here we have demonstrated an efficient and robust method for ligation of recombinantly produced BoNT core-therapeutics to ligands (either recombinant protein or synthesized peptide), targeting the delivery of SNARE-cleaving protease into specific cell types. Our strategy is dependent on removal of the BoNT/D neuronal receptor binding domain, followed by sortase A-mediated conjugation of the targeting ligand. Functional analyses show that our targeted BoNT proteases bind and enter 
rodent macrophages or sensory neurons, cleave SNAREs and block evoked release of cytokines or pain peptides, thereby possessing anti-inflammatory and/or anti-nociceptive potential.

Production of active botulinum neurotoxins requires strict safety containment not just for the process itself but also for the staff and the laboratory environment. Very few laboratories have the authority to produce these exceptionally potent molecules. This could be achieved by separately expressing two inactive BoNT segments followed by their assembly in reaction tubes in the presence of sortase A. This technology could also be useful for preparing other toxin molecules, such as ricin, diphtheria toxin or Pseudomonas exotoxin. Thus, sortase A mediated ligation technology for producing therapeutic molecules or research tools may offer multiple advantages in addition to no chemical manipulation or activation of the $\mathrm{N}$-peptides and C-peptides: (i) to overcome the safety issues due to toxicity of expressed protein in host; (ii) to attach active targeting proteins which require posttranslational-modifications; (iii) to incorporate of non-native peptides and non-peptidic molecules into proteins; (iv) to attach small fluorescent probes to the targeting peptides during synthesis to track the molecules in the targeted cells. Previously, researchers have used protein fusion, chemical conjugation or protein stapling by exploiting tight interaction among SNAP-25/VAMP2/Syntaxin 1 fragment for protein engineering potent chimeric neurotoxins or retargeted BoNTs [9,28-45].

We chose sortase A mediated technology to engineer BoNT-based targeted therapeutic candidates as potential treatments for RA and/or neuropathic pain. RA poses a major health and economic burden. The pathogenesis of arthritis is not yet fully understood. Nevertheless, the abundance and activation of macrophages in the inflamed synovial membrane/pannus significantly correlate with the severity of RA [46]. No arthritis cure exists at present. The advent of the biotherapeutics has now radically changed the approach to treatment, because these can relieve pain in some patients by blocking the effects of endogenous pain mediators, thereby exerting analgesic and anti-inflammatory actions. Administering monoclonal antibodies against TNF $\alpha$ or IL-6 or their receptors has proven beneficial in clinical therapy of patients with RA [47,48]. Although these bio-therapeutics have yielded encouraging results, their high price, numerous adverse reactions and diminishing efficacy over time emphasize the urgent need for improved versions. Yeh et al. adopted the antibody-mediated delivery method to target BoNT/B protease into macrophages via the $\mathrm{Fc}$ and complement receptor-mediated endocytosis pathway. A BoNT/B and an anti-BoNT/B antibody mixture entered macrophages and blocked the release of cytokines [49]. Herein, exploiting the presence of IL-1R on the macrophage, we produced the recombinant IL-1 $\beta$ and used it as a targeting ligand to bind macrophages for subsequent cytosolic delivery of BoNT/D VAMP-cleaving protease, a step requiring the endosomal membrane channel formation via the $\mathrm{H}_{\mathrm{N}}$ domain. Our results clearly demonstrate that the IL- $1 \beta$-fused BoNT/D core-therapeutic molecule can enter cultured macrophage cell lines as well as murine primary macrophages because of the observed cleavage of its intracellular targets and eventual blockade of cytokine exocytosis, in contrast to non-targeted control. The current study is also in accordance with our earlier findings and other groups' data that VAMP3 is required for IL-6 release [26,50]. Previous report has claimed that a BoNT lacking the binding domain was able to enter cultured cells and cleave intracellular targets, albeit at high concentrations [51]. We observed some cleavage of VAMP3 and inhibition of IL-6 release in our non-targeted control toxin-treated samples. Due to the phagocytic nature of macrophage cells, we speculate that this effect may be mediated by non-specific endocytosis of the control toxin. That said, as addition of the IL-1 $\beta$ ligand allowed for specific targeting of the BoNT/D protease into IL-1R-expressing macrophages and enhancing the efficacy of this modified BoNT/D, we believe that our recombinant targeted toxin would be a potent and effective treatment for RA.

Peripheral nerve injury results in the release of several pain-peptides from primary nociceptive afferents. These include substance $P$ and CGRP, which are involved in nociceptive processing in both the peripheral and the central nervous systems [52]. They also regulate various functions of cells, including macrophages, synoviocytes and $\mathrm{T}$ cells and augment the production of pro-inflammatory cytokines, prostaglandin E2 or collagenase [53-55]. Thus, developing new therapeutics either inhibiting 
the release of these two neuropeptides or blocking their receptor activation is fully warranted [56,57]. $\mathrm{CGRP}_{8-37}$ has been demonstrated to inhibit vasodilation and neurogenic inflammation in animal models due to blocking binding of endogenous CGRP to CGRP receptors. However, its clinical effectiveness is limited due to its short half-life [27]. Interestingly, Dragon's blood, which is a traditional Chinese medicine, can control inflammation and relieve pain symptoms by inhibiting the secretion of substance P [58]. Moreover, local injection of BoNT/A complexes or recombinantly engineered BoNTs attenuated the neuropathic pain in rodent models [59-61], perhaps by blocking pain-peptide release from peripheral nociceptive fibers. In this study, we selected $\mathrm{CGRP}_{8-37}$ as a targeting ligand for selective delivery of BoNT/D protease into sensory neurons with the aim of attenuating pain-peptide release. /D-CGRP ${ }_{8-37}$ gave much more pronounced cleavage of VAMP1 and inhibition of depolarization-evoked substance P release from cultured mouse DRGs than non-targeted control proteins, highlighting the specific uptake of BoNT/D protease through the ligated $\mathrm{CGRP}_{8-37}$ ligand. Although inhibition of substance P release by/D-CGRP $8-37$ was incomplete, this might be due to only a subpopulation of DRGs co-expressing CGRP receptor and neuropeptide [25]. We also produced CGRP ${ }_{8-37}$ fused BoNT/D core therapeutic fusion protein in E.coli, which proved a lack of significant improvement in SNARE cleavage and inhibition of neuropeptides release from DRGs when compared to non-targeted control protein. It seems that C-terminal amidation of $\mathrm{CGRP}_{8-37}$ is essential for targeting efficacy. This hypothesis accords with an earlier finding that replacement of the C-terminal amide in CGRP peptide with a carboxyl results in substantial reduction in human CGRP receptor 1 affinity [62]. This also proves the advantages of using sortase A mediated strategy by independently producing two active therapeutic components. An earlier study reported that an intracisternal injection of a chemically conjugated substance P-LC/A decreased thermal hyperalgesia in a mouse model of Taxol induced neuropathic pain [63]. A recent study reported that intrathecal administration of a stapled LC. $\mathrm{H}_{\mathrm{N}} / \mathrm{A}$-substance $\mathrm{P}$ conjugate induced long-term reduction of inflammatory and neuropathic pain sensitivity in mice [39]. We also tried to use synthesized substance $P$ as a targeting ligand and found substance $P$ is slightly less effective than $\mathrm{CGRP}_{8-37}$ at delivering BoNT/D protease into DRGs, as reflected by the extent of VAMP1 cleavage (Figure S4).

The targeted delivery of a SNARE protease to specific neuronal subtypes or non-neuronal cells represents a revolutionary approach for pain relief. Overall, we have described a method for protein engineering BoNT-derived targeted molecules-potential therapeutic candidates for treating RA or neuropathic pain. Inhibiting the release of pro-inflammatory cytokines or major pain neuropeptides by these reagents encourages further studies on effects of these candidates on animal models of inflammatory and neuropathic pain.

\section{Materials and Methods}

\subsection{Materials}

Talon cobalt resin was supplied by Clontech Laboratories, Inc. (Mountain View, CA, USA). Resource Q and PD-10 columns were bought from GE Healthcare (Dublin, Ireland). Thrombin enzyme, vectors and the enhanced chemiluminescence reagent (ECL) were ordered from Merck Millipore (Cork, Ireland). Enterokinase and restriction enzymes were bought from New England Biolabs (Dublin, Ireland). RAW 264.7 cell line murine macrophage and rabbit anti-rat CGRP polyclonal antibody were ordered from Sigma-Aldrich (Arklow, Ireland). Mouse nerve growth factor (NGF-2.5S) was bought from Alomone Labs (Jerusalem, Israel). Zeba Spin Desalting Columns, B-27 Supplement and Collagenase I were supplied by Life Technologies Ltd. (Paisley, UK). Dispase II was bought from Roche Products Ltd. (Dublin, Ireland). Human IL-1 $\beta$ and mouse IL-6 Duo-set ELISA kits were obtained from R\&D Systems Eire (Abingdon, UK). SP enzyme immunoassay (EIA) kit from Cayman Chemical was supplied by Bertin Bioreagent (York, UK). Rabbit anti-rat SP polyclonal antibody was ordered from Enzo Life Sciences LTD (Exeter, UK). Synaptic Systems GmbH (Goettingen, Gremany) supplied rabbit VAMP1/2/3 polyclonal antibody and VAMP1 monoclonal antibody. Horseradish 
peroxidase-conjugated donkey anti-rabbit and anti-mouse secondary antibodies were purchased from Jackson ImmunoResearch (Suffolk, UK). Click-iT ${ }^{\circledR}$ EdU microplate assay kit and Bolt 12\% Bis-Tris gels were purchased from Bio-Sciences (Dun Laoghaire, Ireland). Rat Gly ${ }_{3}-\mathrm{CGRP}_{8-37}$ and $\mathrm{Gly}_{3}$-substance $P$ peptides with C-terminal amide modifications were synthesized by LifeTein, LLC (Somerset, NJ, USA). All other reagents and chemicals were ordered from Sigma-Aldrich (Arklow, Ireland). Gene synthesis and DNA sequencing were serviced by Eurofins Genomics (Ebersberg, Germany). pet30b-7M SrtA encoding hepta-mutant Staphylococcus aureus sortase A was a gift from Hidde Ploegh (Addgene plasmid number 51141).

\subsection{Animal Ethics Statement}

Sprague Dawley rat pups and CD1 mice were bred in the Bio Resources Unit, Dublin City University (DCU). All of the procedures involving living animals were approved by the Dublin City University Research Ethics Committee and by the Health Products Regulatory Authority under Directive 2010/63/EU and the European Union (Protection of Animals Used for Scientific Purposes) Regulations 2012 (S.I. number 543 of 2012).

\subsection{Production of $/ D \Delta H_{C}-C S$, Trx- $H_{6}-I L-1 \beta$ and Sortase $A$}

The experiment involving production of recombinant protein and their treatment with cells was approved by the Dublin City University (DCU) biological Safety Committee and the Environmental Protection Agency of Ireland. The synthetic gene encoding / $\Delta \Delta \mathrm{H}_{\mathrm{C}}$ was cloned into the NdeI and SacI sites in the pET29a vector. A short nucleotide encoding a non-structural linker $2 \times\left(\mathrm{Gly}_{4} \mathrm{Ser}\right)$ and LPETGGGGSGGGGSVDKLLVPRGSKLQ (sortase A motif: bold residues; a thrombin recognition sequence: underlined residues) was cloned into the Sac I and Xho I sites of the $/ \mathrm{D} \Delta \mathrm{H}_{\mathrm{C}}$ plasmid to yield a construct encoding $/ \mathrm{D} \Delta \mathrm{H}_{\mathrm{C}}-\mathrm{CS}$ and a C-terminally fused $\mathrm{His}_{6}$ tag. A synthetic gene encoding Gly ${ }_{5}$-IL-1 $\beta$ was cloned into the $\mathrm{pET} 32 \mathrm{~b}$ vector immediately after the enterokinase recognition site. The yielded constructs and pET30-heptamutant Sortase A (plasmid number 51141; Addgene) were separately transformed into E. coli strain BL21 DE3, and proteins were expressed using an auto-induction medium following the established protocol [64]. Briefly, bacteria overnight grown in Luria-Bertani broth medium were inoculated $(1: 1000 \mathrm{v} / \mathrm{v})$ into ZYP-5052 auto-induction medium and cultured at $37^{\circ} \mathrm{C}$ for $\approx 5 \mathrm{~h}$ with agitation $(220 \mathrm{rpm} / \mathrm{min})$. Bacteria were further cultured at $22^{\circ} \mathrm{C}$ for $\approx 20 \mathrm{~h}$ with continuous shaking before harvesting at $4000 \times g$ for $40 \mathrm{~min}$. Bacterial pellets from $1 \mathrm{~L}$ of culture were re-suspended in $40 \mathrm{~mL}$ of lysis buffer (20 mM HEPES, $145 \mathrm{mM} \mathrm{NaCl}, \mathrm{pH}$ 8.0). After adding lysozyme (to a final concentration of $2 \mathrm{mg} / \mathrm{mL}$ ), 800 units of benzonase nuclease (Millipore, Ireland) and a protease inhibitor cocktail III (1:200 $v / v$, Millipore, Ireland), E. coli cells were lysed at $4{ }^{\circ} \mathrm{C}$ for $1 \mathrm{~h}$. After one freeze-thaw cycle, the lysate was centrifuged at $18,000 \times g$ for $1 \mathrm{~h}$ to remove debris. Recombinant proteins were then purified by IMAC, using Talon superflow metal affinity resin following the provided manual. The purified proteins were buffer exchanged into sample storage buffer $(20 \mathrm{mM}$ Hepes, $145 \mathrm{mM}$ $\mathrm{NaCl}, \mathrm{pH}$ 7.4) using PD-10 columns. The resultant $/ \mathrm{D} \Delta \mathrm{H}_{\mathrm{C}}-\mathrm{CS} S \mathrm{SC}$ was either stored at $-20{ }^{\circ} \mathrm{C}$ or nicked into DC, by thrombin ( $1 \mathrm{U}$ of thrombin/mg of protein for $2 \mathrm{~h}$ at $\left.22^{\circ} \mathrm{C}\right)$, before the addition of phenylmethylsulfonyl fluoride (final concentration $1 \mathrm{mM}$ ). The concentration of nicked $/ \mathrm{D} \Delta \mathrm{H}_{\mathrm{C}}-\mathrm{CS}$ was measured using Bradford reagent. Only the nicked $/ \mathrm{D} \Delta \mathrm{H}_{\mathrm{C}}-\mathrm{CS} \mathrm{DC}$ was used in the conjugation reaction. IMAC purified fusion protein Trx- $\mathrm{H}_{6}-\mathrm{IL}-1 \beta$ was incubated with enterokinase in ratio 1 to $6.25 \times 10^{5}$ for $3 \mathrm{~h}$ at $22{ }^{\circ} \mathrm{C}$ to separate the Trx-His 6 tag from Gly $y_{5}$ IL-1 $\beta$.

\subsection{Conjugation of $/ D \Delta H_{C}-C S$ with IL-1 $\beta$ or Synthesized Peptide}

$/ \mathrm{D} \Delta \mathrm{H}_{\mathrm{C}}-\mathrm{CS}(10 \mu \mathrm{M}$ final concentration) and sortase $\mathrm{A}(25 \mu \mathrm{M}$, final concentration) were mixed with an enterokinase-cleaved Trx-His s $_{6}$ and Gly $y_{5}$ IL- $1 \beta$ mixture $(0.3 \mathrm{mM}$, final concentration) in reaction buffer ( $50 \mathrm{mM}$ Tris, $150 \mathrm{mM} \mathrm{NaCl}, 10 \mathrm{mM} \mathrm{CaCl}_{2}, \mathrm{pH} 7.4$ ) at $37^{\circ} \mathrm{C}$ for the times indicated. To purify the /DIL-1 $\beta$ conjugated protein, the reaction samples were buffer-exchanged into $50 \mathrm{mM}$ Tris buffer ( $\mathrm{pH}$ 8.0) and loaded onto a Resource $\mathrm{Q}$ column following a previously published protocol [29]. Briefly, 
after wash with Tris buffer with $30 \mathrm{mM} \mathrm{NaCl}$, a stepwise gradient up to $1 \mathrm{M} \mathrm{NaCl}$ was used to elute the conjugated protein and other contaminants.

To conjugate $/ \mathrm{D} \Delta \mathrm{H}_{\mathrm{C}}-\mathrm{CS}$ to $\mathrm{Gly}_{3}-\mathrm{CGRP}_{8-37}$ or $\mathrm{Gly}_{3}$-substance $\mathrm{P}, / \mathrm{D} \Delta \mathrm{H}_{\mathrm{C}}-\mathrm{CS}(10 \mu \mathrm{M}$, final concentration) and sortase $\mathrm{A}(25 \mu \mathrm{M}$, final concentration) were mixed with peptides $(0.3 \mathrm{mM}$, final concentration) at $37^{\circ} \mathrm{C}$ for $30 \mathrm{~min}$. The reaction mixture was buffer-exchanged into the sample storage buffer using Zeba Spin Desalting Columns to stop the reaction and remove the excess peptides.

\subsection{Measuring the Protease Activities of /D $\Delta H_{C}$ Variants and the Bio-Activity of IL-1 $\beta$ Ligand}

The proteolytic activities of /DIL-1 $\beta, / \mathrm{D}-C G R P_{8-37}$ and control protein were assessed in vitro using a recombinant GFP-VAMP $(2-94)-\mathrm{His}_{6}$ substrate cleavage assay [65]. Briefly, the proteins were diluted to $100 \mathrm{nM}$ in protease assay buffer HBS-20 (20 mM HEPES, $100 \mathrm{mM} \mathrm{NaCl}(\mathrm{pH} 7.4), 10 \mu \mathrm{g} / \mathrm{mL}$ bovine serum albumin (BSA), $5 \mathrm{mM}$ DTT and $10 \mu \mathrm{M} \mathrm{ZnCl} 2$ ) and incubated at $37^{\circ} \mathrm{C}$ for $30 \mathrm{~min}$ to activate proteases. The proteins $(100 \mathrm{nM})$ were serially diluted (2-fold) to a final concentration of $1.56 \mathrm{nM}$ in HBS-20 buffer then mixed with equal volume of $1 \mathrm{mg} / \mathrm{mL}$ of GFP-VAMP $(2-94)-\mathrm{His}_{6}$ substrates. Following additional $30 \mathrm{~min}$ incubation at $37^{\circ} \mathrm{C}$, the reactions were stopped by adding equal reaction volume of ice-cold $2 \times$ LDS sample buffer. The samples were analyzed by running on $12 \%$ Tris-glycine SDS-PAGE gels and stained by Coomassie solution.

The bio-activity of purified /DIL-1 $\beta$ was measured by the cell proliferation assay. RAW 264.7 cells were plated in a 96 well plate with $\approx 0.4 \times 10^{4}$ cells/well, and cultured in Dulbecco's modified Eagle's medium (DMEM) containing 10\% $(v / v)$ heat-inactivated fetal bovine serum (FBS) and $1 \%(v / v)$ penicillin streptomycin, for $24 \mathrm{~h}$ at $37^{\circ} \mathrm{C}$, with $5 \% \mathrm{CO}_{2}$. After $24 \mathrm{~h}$ incubation, a range of two-fold serial dilutions of commercial human IL-1 $\beta$ (from $500 \mathrm{pg} / \mathrm{mL}$ to $0.98 \mathrm{pg} / \mathrm{mL}$ ), serial diluted $/ \mathrm{DIL}-1 \beta$ or $/ \mathrm{D} \Delta \mathrm{H}_{\mathrm{C}}-\mathrm{CS}$ were added to the plate and incubated for a further $48 \mathrm{~h}$ at $37^{\circ} \mathrm{C}$, with $5 \% \mathrm{CO}_{2}$. Treated cells were labelled with $10 \mu \mathrm{M}$ of EdU for $16 \mathrm{~h}$ before fixation, which was followed by Click-iT ${ }^{\circledR}$ EdU microplate assaying, according to the manual. Finally, the fluorescence, excitation/emission maxima 490/530 or 530/590 nM, was read using a plate reader. The percentage of bio-activity of the test proteins was calculated relative to the commercial human IL-1 $\beta$ using the standard curve based on data obtained using the human IL-1 $\beta$.

\subsection{Isolation and Culturing Primary Mouse Peritoneal Macrophages and Rat DRGs}

Mouse peritoneal macrophages were isolated from the peritoneal cavity of around 8 week old CD1 mice and cultured in vitro, according to a protocol published by Zhang et al. [66]. Briefly, the skin at the front of the peritoneum was separated and removed from the peritoneum. A total of $5 \mathrm{~mL}$ of chilled Dulbecco's phosphate-buffered saline (DPBS) was injected inter-peritoneally, and then fluid was collected from the peritoneal cavity. The collected fluid was centrifuged at $120 \times g$ for $8 \mathrm{~min}$. The cell pellet was resuspended in a culture medium (DMEM/Nutrient F12 ham, 10\% $(v / v)$ FBS, 1\% $(v / v)$ penicillin streptomycin) and seeded $\approx 4 \times 10^{5}$ cells per well into a 24 well plate. After $1 \mathrm{~h}$ incubation at $37^{\circ} \mathrm{C}$, with $5 \% \mathrm{CO}_{2}$, the cells were washed with warmed DPBS three times, fresh culture medium was added and it was incubated for a further $24 \mathrm{~h}$. More than $90 \%$ of cells should be macrophages [66].

rDRGs were isolated and cultured, following the published protocols $[67,68]$. Briefly, the dorsal root ganglion dissected from Sprague Dawley post-natal 0-3 rats were centrifuged for $1 \mathrm{~min}$ at $120 \mathrm{~g}$. The isolated DRGs were then incubated at $37^{\circ} \mathrm{C}$ for $30 \mathrm{~min}$ with DMEM medium, containing $2.4 \mathrm{U} / \mathrm{mL}$ dispase II and $5 \mathrm{mg} / \mathrm{mL}$ collagenase I. Following centrifugation for $5 \mathrm{~min}$ at $120 \mathrm{~g}$, pellets were resuspended in DMEM medium with gentle trituration until cloudy. After centrifugation for $5 \mathrm{~min}$ at $120 \mathrm{~g}$, cell pellets were resuspended in culture medium (DMEM medium containing $5 \%(v / v)$ FBS, $1 \%(v / v)$ penicillin/streptomycin, $50 \mathrm{ng} / \mathrm{mL} 2.5 \mathrm{~S}$ NGF and $1 \times \mathrm{B}-27$ supplement), and then $\approx 5 \times 10^{5}$ cells/well were seeded in 48 well plates which were pre-coated with poly-L-lysine $(0.1 \mathrm{mg} / \mathrm{mL})$ and laminin $(20 \mu \mathrm{g} / \mathrm{mL})$. From day one onwards, cytosine- $\beta$-D-arabinofuranoside (Ara-C) $(10 \mu \mathrm{M})$ was added into the culture medium, which was replaced every other day. 


\subsection{Treatment of Macrophages with/DIL-1 $\beta$ or/D $\Delta H_{C^{-}}$CS, Measuring VAMP3 Cleavage and IL-6 Release}

After seeding the RAW cells $\left(\approx 1 \times 10^{5}\right.$ cells per well) or primary mouse macrophages $\left(\approx 4 \times 10^{5}\right.$ cells per well) in a 24 well plate for $24 \mathrm{~h}$ at $37^{\circ} \mathrm{C}, 5 \% \mathrm{CO}_{2}$, the cells were incubated with a range of two-fold serial dilutions of DIL- $1 \beta$ or control protein for $6 \mathrm{~h}$ at $37^{\circ} \mathrm{C}$, with $5 \% \mathrm{CO}_{2}$. After removal of the medium, pre-treated macrophages were incubated with $0.3 \mathrm{~mL}$ stimulation solution (DMEM medium (RAW cells) or DMEM/Nutrient F12 ham (primary mouse macrophages), containing $100 \mathrm{ng} / \mathrm{mL}$ LPS, $500 \mathrm{pg} / \mathrm{mL} \mathrm{IFN} \gamma$ and $1 \%$ penicillin/streptomycin) for $42 \mathrm{~h}$ at $37{ }^{\circ} \mathrm{C}$, with $5 \% \mathrm{CO}_{2}$ [49]. Then the supernatants were collected, and IL- 6 concentration was analyzed by ELISA following instructions for the kit. Treated macrophages were lysed in $70 \mu \mathrm{L}$ of $2 \times \mathrm{LDS}$ sample buffer, heated for $10 \mathrm{~min}$ at $95^{\circ} \mathrm{C}$ and run on Bolt $12 \%$ Bis-Tris gels. Samples were transferred onto a PVDF membrane and probed with rabbit anti-SNAP23 (1:1000; 111 202; Synaptic Systems) and anti-VAMP1/2/3 (1:1000; 104 102; Synaptic Systems) antibodies overnight at $4{ }^{\circ} \mathrm{C}$, followed by incubation with HRP donkey anti-rabbit secondary antibodies for $1 \mathrm{~h}$ at room temperature. Finally, blots were developed by ECL reagents and visualized using the G BOX Chemi-16 gel documentation system and intensities in each lane were quantified using Image J software [65].

\subsection{Cell Viability Assay}

The RAW cells were plated into a 96 well plate with $\approx 0.4 \times 10^{5}$ cells/well and cultured for $24 \mathrm{~h}$ at $37^{\circ} \mathrm{C}$, with $5 \% \mathrm{CO}_{2}$. On the following day, the cells were incubated with various concentrations of proteins for $44 \mathrm{~h}$ at $37{ }^{\circ} \mathrm{C}$, with $5 \% \mathrm{CO}_{2}$. Then each well was replaced with $110 \mu \mathrm{L}$ culture medium, containing $10 \mu \mathrm{L}$ alamar blue reagents, and further, incubated for $4 \mathrm{~h}$, before reading absorbance at $570 \mathrm{nM}$ by plate reader.

\subsection{Analysis of VAMP1 Cleavage and SP Release in rDRGs}

After 6-7 days in vitro, the rDRGs were incubated with various doses of /D-CGRP $8-37$ or $/ \mathrm{D} \Delta \mathrm{H}_{\mathrm{C}}-\mathrm{CS}$ for $24 \mathrm{~h}$ at $37^{\circ} \mathrm{C}$, with $5 \% \mathrm{CO}_{2}$. Before harvesting, treated rDRGs were incubated with $0.2 \mathrm{~mL}$ of $\mathrm{K}^{+}$ stimulation buffer (mM; 22.5 HEPES, $75 \mathrm{NaCl}, 63.5 \mathrm{KCl}, 1 \mathrm{MgCl}_{2}, 2.5 \mathrm{CaCl}_{2}, 3.3$ glucose and $0.1 \%(w / v)$ BSA, pH 7.4) for $30 \mathrm{~min}$ at $37^{\circ} \mathrm{C}$, with $5 \% \mathrm{CO}_{2}$ [68]. The basal release was measured by incubation of other spare cells with $3.5 \mathrm{mM}$ low potassium (LK) buffer with adjusting of $\mathrm{NaCl}$ concentration to reach isotonic balance [68]. The supernatants were then collected and used for SP EIA analysis, according to instructions provided with the kit. Treated rat DRGs were lysed in $60 \mu \mathrm{L} 2 \times$ LDS sample buffer and analyzed by Western blotting using a rabbit antibody which recognizes intact VAMP1 but not BoNT/D in cleaved form (1:1000; 104 002; Synaptic Systems). VAMP1 cleavage was normalized according to a loading control (syntaxin 1 ) before analysis relative to the toxin free control cells.

\subsection{Statistical Analysis}

All the raw data were analyzed using Microsoft Excel 2010. Graph Pad Prism 4.0 was used to plot the calculated data points and perform the statistical analysis. The number of independent experiments ( $n$ value) represented in a graph is highlighted in the corresponding figure legends. The significance between treatments was evaluated using the student's unpaired, two-tailed $t$-test.

Supplementary Materials: The following are available online at http:/www.mdpi.com/1422-0067/21/1/262/s1.

Author Contributions: Conceptualization, J.M. and J.W.; data curation, M.T.; formal analysis, M.T., J.M. and J.W.; funding acquisition, J.W. and J.M.; investigation (J.W. created the constructs. M.T. produced the conjugates and performed functional characterization of conjugates), M.T. and J.W.; project administration, J.M. and J.W.; supervision, J.M. and J.W.; writing—original draft, M.T. and J.W.; writing-review and editing, J.M. and J.W. All authors have read and agreed to the published version of the manuscript.

Funding: This research was funded by Science Foundation Ireland through a Career Development Award (13/CDA/2093), a SFI Technology Innovation Development Award (17/TIDA/4977) and a Starting Investigator Research Grant (15/SIRG/3508). 
Acknowledgments: The authors thank Oliver Dolly for hosting this project in the International Centre for Neurotherapeutics and allowing access to his equipment. Thanks also to Ciara Larkin for proof-reading this manuscript.

Conflicts of Interest: The authors declare no conflict of interest. The funder had no role in the design of the study; in the collection, analyses, or interpretation of data; in the writing of the manuscript, or in the decision to publish the results.

\section{Abbreviations}

\begin{tabular}{|c|c|}
\hline AEX & Anion-exchange chromatography \\
\hline Ara-C & Cytosine- $\beta$-D-arabinofuranoside \\
\hline BoNT & Botulinum neurotoxin \\
\hline BoNT/D & Botulinum neurotoxin D \\
\hline BOTOX & Botulinum toxin A complex \\
\hline CGRP & Calcitonin gene-related peptide \\
\hline CGRP $_{8-37}$ & CGRP receptor antagonist \\
\hline CS & C-terminal sortase motif \\
\hline DC & Di-chain \\
\hline$/ \mathrm{D} \Delta \mathrm{H}_{\mathrm{C}}$ & BoNT/D lacking the neuronal binding domain $\mathrm{H}_{\mathrm{C}}$ \\
\hline /D-CGRP $8-37$ & $/ \mathrm{D} \Delta \mathrm{H}_{\mathrm{C}}-\mathrm{CS}$ and $\mathrm{CGRP}_{8-37}$ ligated conjugate \\
\hline$/ \mathrm{DIL}-1 \beta$ & $/ \mathrm{D} \Delta \mathrm{H}_{\mathrm{C}}-\mathrm{CS}$ and IL- $1 \beta$ ligated conjugate \\
\hline DMEM & Dulbecco's modified Eagle's medium \\
\hline DPBS & Dulbecco's phosphate-buffered saline \\
\hline DRGs & Dorsal root ganglion neurons \\
\hline DTT & Dithiothreitol \\
\hline ECL & Enhanced chemiluminescence reagent \\
\hline EIA & Enzyme immunoassay \\
\hline FBS & Fetal bovine serum \\
\hline $\mathrm{H}_{6}$ & His6 tag \\
\hline $\mathrm{HC}$ & Heavy chain domain \\
\hline $\mathrm{H}_{\mathrm{C}}$ & C-terminal half of $\mathrm{H}_{\mathrm{C}}$ \\
\hline HK & High potassium \\
\hline $\mathrm{H}_{\mathrm{N}}$ & $\mathrm{N}$-terminal half of $\mathrm{H}_{\mathrm{C}}$ \\
\hline $\mathrm{IFN} \gamma$ & Interferon gamma \\
\hline IL-1 $\beta$ & Interleukin $1 \beta$ \\
\hline $\mathrm{LC}$ & Light chain domain \\
\hline LK & Low potassium \\
\hline LPS & Lipopolysaccharides \\
\hline NGF-2.5S & Nerve growth factor $2.5 \mathrm{~S}$ \\
\hline NSAIDs & Nonsteroidal anti-inflammatory drugs \\
\hline RA & Rheumatoid arthritis \\
\hline SC & Single-chain \\
\hline SNAP-25 & Synaptosomal-associated protein $25 \mathrm{k}$ \\
\hline SNAREs & Soluble $N$-ethylmaleimide-sensitive factor attachment protein receptors \\
\hline $\mathrm{TNF} \alpha$ & Tumor necrosis factor- $\alpha$ \\
\hline $\operatorname{Trx}$ & Thioredoxin tag \\
\hline $\operatorname{Tr} x-\mathrm{H}_{6}$ & $\mathrm{Tr}^{-}-\mathrm{His}_{6}$ tag \\
\hline $\operatorname{Tr} x-\mathrm{H}_{6}-\mathrm{IL}-1 \beta$ & Thioredoxin-His ${ }_{6}$-Gly 5 -IL-1 $\beta$ protein \\
\hline US & Unstimulated \\
\hline VAMP & Vesicle associated membrane protein \\
\hline
\end{tabular}

\section{References}

1. Volkow, N.D.; McLellan, A.T. Opioid Abuse in Chronic Pain-Misconceptions and Mitigation Strategies. N. Engl. J. Med. 2016, 374, 1253-1263. [CrossRef] [PubMed] 
2. Binder, W.J.; Brin, M.F.; Blitzer, A.; Schoenrock, L.D.; Pogoda, J.M. Botulinum toxin type A (BOTOX) for treatment of migraine headaches: An open-label study. Otolaryngol. Head Neck Surg. 2000, 123, 669-676. [CrossRef]

3. Dover, N.; Barash, J.R.; Hill, K.K.; Xie, G.; Arnon, S.S. Molecular characterization of a novel botulinum neurotoxin type H gene. J. Infect. Dis. 2014, 209, 192-202. [CrossRef]

4. Pirazzini, M.; Azarnia Tehran, D.; Zanetti, G.; Rossetto, O.; Montecucco, C. Hsp90 and Thioredoxin-Thioredoxin Reductase enable the catalytic activity of Clostridial neurotoxins inside nerve terminals. Toxicon 2018, 147, 32-37. [CrossRef]

5. Gonzalez-Escalona, N.; Thirunavukkarasu, N.; Singh, A.; Toro, M.; Brown, E.W.; Zink, D.; Rummel, A.; Sharma, S.K. Draft Genome Sequence of Bivalent Clostridium botulinum Strain IBCA10-7060, Encoding Botulinum Neurotoxin B and a New FA Mosaic Type. Genome Announc. 2014, 2. [CrossRef]

6. Pellett, S.; Tepp, W.H.; Bradshaw, M.; Kalb, S.R.; Dykes, J.K.; Lin, G.; Nawrocki, E.M.; Pier, C.L.; Barr, J.R.; Maslanka, S.E.; et al. Purification and Characterization of Botulinum Neurotoxin FA from a Genetically Modified Clostridium botulinum Strain. mSphere 2016, 1. [CrossRef]

7. Maslanka, S.E.; Luquez, C.; Dykes, J.K.; Tepp, W.H.; Pier, C.L.; Pellett, S.; Raphael, B.H.; Kalb, S.R.; Barr, J.R.; Rao, A.; et al. A Novel Botulinum Neurotoxin, Previously Reported as Serotype H, Has a Hybrid-Like Structure With Regions of Similarity to the Structures of Serotypes A and F and Is Neutralized With Serotype A Antitoxin. J. Infect. Dis. 2016, 213, 379-385. [CrossRef]

8. Tehran, D.A.; Pirazzini, M. Novel Botulinum Neurotoxins: Exploring Underneath the Iceberg Tip. Toxins 2018, 10, 190. [CrossRef]

9. Zhang, S.; Masuyer, G.; Zhang, J.; Shen, Y.; Lundin, D.; Henriksson, L.; Miyashita, S.I.; Martinez-Carranza, M.; Dong, M.; Stenmark, P. Identification and characterization of a novel botulinum neurotoxin. Nat. Commun. 2017, 8, 14130. [CrossRef]

10. Meng, J.; Wang, J. Role of SNARE proteins in tumourigenesis and their potential as targets for novel anti-cancer therapeutics. Biochim. Biophys. Acta 2015, 1856, 1-12. [CrossRef] [PubMed]

11. Montal, M. Botulinum neurotoxin: A marvel of protein design. Annu. Rev. Biochem. 2010, 79, 591-617. [CrossRef]

12. Boudreau, G.P.; Grosberg, B.M.; McAllister, P.J.; Lipton, R.B.; Buse, D.C. Prophylactic onabotulinumtoxinA in patients with chronic migraine and comorbid depression: An open-label, multicenter, pilot study of efficacy, safety and effect on headache-related disability, depression, and anxiety. Int. J. Gen. Med. 2015, 8, 79-86. [CrossRef]

13. Wang, J.; Zurawski, T.H.; Meng, J.; Lawrence, G.; Olango, W.M.; Finn, D.P.; Wheeler, L.; Dolly, J.O. A dileucine in the protease of botulinum toxin A underlies its long-lived neuroparalysis: Transfer of longevity to a novel potential therapeutic. J. Biol. Chem. 2011, 286, 6375-6385. [CrossRef]

14. Matak, I.; Bolcskei, K.; Bach-Rojecky, L.; Helyes, Z. Mechanisms of Botulinum Toxin Type A Action on Pain. Toxins 2019, 11, 459. [CrossRef] [PubMed]

15. Ma, Y.; Pope, R.M. The role of macrophages in rheumatoid arthritis. Curr. Pharm. Des. 2005, 11, 569-580. [CrossRef]

16. Scheller, J.; Chalaris, A.; Schmidt-Arras, D.; Rose-John, S. The pro- and anti-inflammatory properties of the cytokine interleukin-6. Biochim. Biophys. Acta 2011, 1813, 878-888. [CrossRef]

17. Muller-Ladner, U.; Pap, T.; Gay, R.E.; Neidhart, M.; Gay, S. Mechanisms of disease: The molecular and cellular basis of joint destruction in rheumatoid arthritis. Nat. Clin. Pract. Rheumatol. 2005, 1, 102-110. [CrossRef]

18. Ji, H.; Pettit, A.; Ohmura, K.; Ortiz-Lopez, A.; Duchatelle, V.; Degott, C.; Gravallese, E.; Mathis, D.; Benoist, C. Critical roles for interleukin 1 and tumor necrosis factor alpha in antibody-induced arthritis. J. Exp. Med. 2002, 196, 77-85. [CrossRef]

19. Schaible, H.-G. Nociceptive neurons detect cytokines in arthritis. Arthritis Res. Ther. 2014, 16, 470. [CrossRef]

20. Murray, R.Z.; Stow, J.L. Cytokine Secretion in Macrophages: SNAREs, Rabs, and Membrane Trafficking. Front. Immunol. 2014, 5, 538. [CrossRef]

21. Murray, R.Z.; Kay, J.G.; Sangermani, D.G.; Stow, J.L. A role for the phagosome in cytokine secretion. Science 2005, 310, 1492-1495. [CrossRef] [PubMed]

22. Mao, H.; Hart, S.A.; Schink, A.; Pollok, B.A. Sortase-mediated protein ligation: A new method for protein engineering. J. Am. Chem. Soc. 2004, 126, 2670-2671. [CrossRef] [PubMed] 
23. Dinarello, C.A. Interleukin-1 and interleukin-1 antagonism. Blood 1991, 77, 1627-1652. [CrossRef] [PubMed]

24. Chizzonite, R.; Truitt, T.; Kilian, P.L.; Stern, A.S.; Nunes, P.; Parker, K.P.; Kaffka, K.L.; Chua, A.O.; Lugg, D.K.; Gubler, U. Two high-affinity interleukin 1 receptors represent separate gene products. Proc. Natl. Acad. Sci. USA 1989, 86, 8029-8033. [CrossRef]

25. Segond von Banchet, G.; Pastor, A.; Biskup, C.; Schlegel, C.; Benndorf, K.; Schaible, H.G. Localization of functional calcitonin gene-related peptide binding sites in a subpopulation of cultured dorsal root ganglion neurons. Neuroscience 2002, 110, 131-145. [CrossRef]

26. Boddul, S.V.; Meng, J.; Dolly, J.O.; Wang, J. SNAP-23 and VAMP-3 contribute to the release of IL-6 and TNFalpha from a human synovial sarcoma cell line. FEBS J. 2014, 281, 750-765. [CrossRef]

27. Durham, P.L. CGRP-receptor antagonists-a fresh approach to migraine therapy? N. Engl. J. Med. 2004, 350, 1073-1075. [CrossRef]

28. Wang, J.; Zurawski, T.H.; Meng, J.; Lawrence, G.W.; Aoki, K.R.; Wheeler, L.; Dolly, J.O. Novel chimeras of botulinum and tetanus neurotoxins yield insights into their distinct sites of neuroparalysis. FASEB J. 2012, 26, 5035-5048. [CrossRef]

29. Wang, J.; Meng, J.; Lawrence, G.W.; Zurawski, T.H.; Sasse, A.; Bodeker, M.O.; Gilmore, M.A.; Fernandez-Salas, E.; Francis, J.; Steward, L.E.; et al. Novel chimeras of botulinum neurotoxins A and E unveil contributions from the binding, translocation, and protease domains to their functional characteristics. J. Biol. Chem. 2008, 283, 16993-17002. [CrossRef]

30. Vazquez-Cintron, E.J.; Beske, P.H.; Tenezaca, L.; Tran, B.Q.; Oyler, J.M.; Glotfelty, E.J.; Angeles, C.A.; Syngkon, A.; Mukherjee, J.; Kalb, S.R.; et al. Engineering Botulinum Neurotoxin C1 as a Molecular Vehicle for Intra-Neuronal Drug Delivery. Sci. Rep. 2017, 7, 42923. [CrossRef]

31. Tao, L.; Peng, L.; Berntsson, R.P.; Liu, S.M.; Park, S.; Yu, F.; Boone, C.; Palan, S.; Beard, M.; Chabrier, P.E.; et al. Engineered botulinum neurotoxin B with improved efficacy for targeting human receptors. Nat. Commun. 2017, 8, 53. [CrossRef] [PubMed]

32. Stancombe, P.R.; Masuyer, G.; Birch-Machin, I.; Beard, M.; Foster, K.A.; Chaddock, J.A.; Acharya, K.R. Engineering botulinum neurotoxin domains for activation by toxin light chain. FEBS J. 2012, 279, 515-523. [CrossRef] [PubMed]

33. Masuyer, G.; Chaddock, J.A.; Foster, K.A.; Acharya, K.R. Engineered botulinum neurotoxins as new therapeutics. Ann. Rev. Pharmacol. Toxicol. 2014, 54, 27-51. [CrossRef] [PubMed]

34. Foster, K.A.; Adams, E.J.; Durose, L.; Cruttwell, C.J.; Marks, E.; Shone, C.C.; Chaddock, J.A.; Cox, C.L.; Heaton, C.; Sutton, J.M.; et al. Re-engineering the target specificity of Clostridial neurotoxins-A route to novel therapeutics. Neurotox. Res. 2006, 9, 101-107. [CrossRef] [PubMed]

35. Foster, K.A. Engineered toxins: New therapeutics. Toxicon 2009, 54, 587-592. [CrossRef]

36. Ferrari, E.; Maywood, E.S.; Restani, L.; Caleo, M.; Pirazzini, M.; Rossetto, O.; Hastings, M.H.; Niranjan, D.; Schiavo, G.; Davletov, B. Re-assembled botulinum neurotoxin inhibits CNS functions without systemic toxicity. Toxins 2011, 3, 345-355. [CrossRef]

37. Ferrari, E.; Gu, C.; Niranjan, D.; Restani, L.; Rasetti-Escargueil, C.; Obara, I.; Geranton, S.M.; Arsenault, J.; Goetze, T.A.; Harper, C.B.; et al. Synthetic self-assembling clostridial chimera for modulation of sensory functions. Bioconjugate Chem. 2013, 24, 1750-1759. [CrossRef]

38. Arsenault, J.; Ferrari, E.; Niranjan, D.; Cuijpers, S.A.; Gu, C.; Vallis, Y.; O’Brien, J.; Davletov, B. Stapling of the botulinum type A protease to growth factors and neuropeptides allows selective targeting of neuroendocrine cells. J. Neurochem. 2013, 126, 223-233. [CrossRef]

39. Maiaru, M.; Leese, C.; Certo, M.; Echeverria-Altuna, I.; Mangione, A.S.; Arsenault, J.; Davletov, B.; Hunt, S.P. Selective neuronal silencing using synthetic botulinum molecules alleviates chronic pain in mice. Sci. Transl. Med. 2018, 10, eaar7384. [CrossRef]

40. Darios, F.; Niranjan, D.; Ferrari, E.; Zhang, F.; Soloviev, M.; Rummel, A.; Bigalke, H.; Suckling, J.; Ushkaryov, Y.; Naumenko, N.; et al. SNARE tagging allows stepwise assembly of a multimodular medicinal toxin. Proc. Natl. Acad. Sci. USA 2010, 107, 18197-18201. [CrossRef]

41. Webb, R.P. Engineering of Botulinum Neurotoxins for Biomedical Applications. Toxins 2018, 10, 231. [CrossRef] [PubMed]

42. Fonfria, E.; Elliott, M.; Beard, M.; Chaddock, J.A.; Krupp, J. Engineering Botulinum Toxins to Improve and Expand Targeting and SNARE Cleavage Activity. Toxins 2018, 10, 278. [CrossRef] [PubMed] 
43. Somm, E.; Bonnet, N.; Martinez, A.; Marks, P.M.; Cadd, V.A.; Elliott, M.; Toulotte, A.; Ferrari, S.L.; Rizzoli, R.; Huppi, P.S.; et al. A botulinum toxin-derived targeted secretion inhibitor downregulates the GH/IGF1 axis. J. Clin. Investig. 2012, 122, 3295-3306. [CrossRef] [PubMed]

44. Kutschenko, A.; Weisemann, J.; Kollewe, K.; Fiedler, T.; Alvermann, S.; Boselt, S.; Escher, C.; Garde, N.; Gingele, S.; Kaehler, S.B.; et al. Botulinum neurotoxin serotype D-A potential treatment alternative for BoNT/A and B non-responding patients. Clin. Neurophysiol. 2019, 130, 1066-1073. [CrossRef] [PubMed]

45. Weisemann, J.; Krez, N.; Fiebig, U.; Worbs, S.; Skiba, M.; Endermann, T.; Dorner, M.B.; Bergstrom, T.; Munoz, A.; Zegers, I.; et al. Generation and Characterization of Six Recombinant Botulinum Neurotoxins as Reference Material to Serve in an International Proficiency Test. Toxins 2015, 7, 5035-5054. [CrossRef] [PubMed]

46. Kinne, R.W.; Brauer, R.; Stuhlmuller, B.; Palombo-Kinne, E.; Burmester, G.R. Macrophages in rheumatoid arthritis. Arthritis Res. 2000, 2, 189-202. [CrossRef]

47. Ternant, D.; Bejan-Angoulvant, T.; Passot, C.; Mulleman, D.; Paintaud, G. Clinical Pharmacokinetics and Pharmacodynamics of Monoclonal Antibodies Approved to Treat Rheumatoid Arthritis. Clin. Pharm. 2015, 54, 1107-1123. [CrossRef]

48. Feldmann, M. Development of anti-TNF therapy for rheumatoid arthritis. Nat. Rev. Immunol. 2002, 2, 364-371. [CrossRef]

49. Yeh, F.L.; Zhu, Y.; Tepp, W.H.; Johnson, E.A.; Bertics, P.J.; Chapman, E.R. Retargeted clostridial neurotoxins as novel agents for treating chronic diseases. Biochemistry 2011, 50, 10419-10421. [CrossRef]

50. Manderson, A.P.; Kay, J.G.; Hammond, L.A.; Brown, D.L.; Stow, J.L. Subcompartments of the macrophage recycling endosome direct the differential secretion of IL-6 and TNFalpha. J. Cell Biol. 2007, 178, 57-69. [CrossRef]

51. Fischer, A.; Mushrush, D.J.; Lacy, D.B.; Montal, M. Botulinum neurotoxin devoid of receptor binding domain translocates active protease. PLoS Pathog. 2008, 4, e1000245. [CrossRef] [PubMed]

52. Dubin, A.E.; Patapoutian, A. Nociceptors: The sensors of the pain pathway. J. Clin. Investig. 2010, 120, 3760-3772. [CrossRef] [PubMed]

53. Yaraee, R.; Ebtekar, M.; Ahmadiani, A.; Sabahi, F. Neuropeptides (SP and CGRP) augment pro-inflammatory cytokine production in HSV-infected macrophages. Int. Immunopharmacol. 2003, 3, 1883-1887. [CrossRef]

54. Lotz, M.; Carson, D.A.; Vaughan, J.H. Substance P activation of rheumatoid synoviocytes: Neural pathway in pathogenesis of arthritis. Science 1987, 235, 893-895. [CrossRef]

55. Delgado, A.V.; McManus, A.T.; Chambers, J.P. Production of tumor necrosis factor-alpha, interleukin 1-beta, interleukin 2, and interleukin 6 by rat leukocyte subpopulations after exposure to substance P. Neuropeptides 2003, 37, 355-361. [CrossRef]

56. Edvinsson, L.; Haanes, K.A.; Warfvinge, K.; Krause, D.N. CGRP as the target of new migraine therapies-Successful translation from bench to clinic. Nat. Rev. Neurol. 2018, 14, 338-350. [CrossRef]

57. Edvinsson, L.; Haanes, K.A.; Warfvinge, K. Does inflammation have a role in migraine? Nat. Rev. Neurol. 2019, 15, 483-490. [CrossRef]

58. Li, Y.S.; Wang, J.X.; Jia, M.M.; Liu, M.; Li, X.J.; Tang, H.B. Dragon's blood inhibits chronic inflammatory and neuropathic pain responses by blocking the synthesis and release of substance P in rats. J. Pharmacol. Sci. 2012, 118, 43-54. [CrossRef]

59. Wang, J.; Casals-Diaz, L.; Zurawski, T.; Meng, J.; Moriarty, O.; Nealon, J.; Edupuganti, O.P.; Dolly, O. A novel therapeutic with two SNAP-25 inactivating proteases shows long-lasting anti-hyperalgesic activity in a rat model of neuropathic pain. Neuropharmacology 2017, 118, 223-232. [CrossRef]

60. Park, H.J.; Lee, Y.; Lee, J.; Park, C.; Moon, D.E. The effects of botulinum toxin A on mechanical and cold allodynia in a rat model of neuropathic pain. Can. J. Anaesth. 2006, 53, 470-477. [CrossRef]

61. Mangione, A.S.; Obara, I.; Maiaru, M.; Geranton, S.M.; Tassorelli, C.; Ferrari, E.; Leese, C.; Davletov, B.; Hunt, S.P. Nonparalytic botulinum molecules for the control of pain. Pain 2016, 157, 1045-1055. [CrossRef] [PubMed]

62. Carpenter, K.A.; Schmidt, R.; von Mentzer, B.; Haglund, U.; Roberts, E.; Walpole, C. Turn structures in CGRP C-terminal analogues promote stable arrangements of key residue side chains. Biochemistry 2001, 40, 8317-8325. [CrossRef] [PubMed] 
63. Mustafa, G.; Anderson, E.M.; Bokrand-Donatelli, Y.; Neubert, J.K.; Caudle, R.M. Anti-nociceptive effect of a conjugate of substance P and light chain of botulinum neurotoxin type A. Pain 2013, 154, 2547-2553. [CrossRef] [PubMed]

64. Studier, F.W. Protein production by auto-induction in high density shaking cultures. Protein Expr. Purif. 2005, 41, 207-234. [CrossRef] [PubMed]

65. Wang, J.; Zurawski, T.H.; Bodeker, M.O.; Meng, J.; Boddul, S.; Aoki, K.R.; Dolly, J.O. Longer-acting and highly potent chimaeric inhibitors of excessive exocytosis created with domains from botulinum neurotoxin A and B. Biochem. J. 2012, 444, 59-67. [CrossRef] [PubMed]

66. Zhang, X.; Goncalves, R.; Mosser, D.M. The isolation and characterization of murine macrophages. Curr. Protoc. Immunol. 2008, 83. [CrossRef]

67. Malin, S.A.; Davis, B.M.; Molliver, D.C. Production of dissociated sensory neuron cultures and considerations for their use in studying neuronal function and plasticity. Nat. Protoc. 2007, 2, 152-160. [CrossRef]

68. Meng, J.; Wang, J.; Lawrence, G.; Dolly, J.O. Synaptobrevin I mediates exocytosis of CGRP from sensory neurons and inhibition by botulinum toxins reflects their anti-nociceptive potential. J. Cell Sci. 2007, 120, 2864-2874. [CrossRef]

(C) 2019 by the authors. Licensee MDPI, Basel, Switzerland. This article is an open access article distributed under the terms and conditions of the Creative Commons Attribution (CC BY) license (http://creativecommons.org/licenses/by/4.0/). 